\section{SOI: $1.1 / \mathrm{TAS} \quad$ DOI: $10.15863 / \mathrm{TAS}$ International Scientific Journal Theoretical \& Applied Science}

p-ISSN: 2308-4944 (print) e-ISSN: 2409-0085 (online)

Year: $2015 \quad$ Issue: $07 \quad$ Volume: 27

Published: $30.07 .2015 \quad$ http://T-Science.org
Tozagul Rajapovna Matyakubova associate professor on the science of philology, Tashkent State Pedagogical University named after Nizomi, Uzbekistan tozagul_matyakubova@mail.ru

SECTION 29. Literature. Folklore. Translation Studies.

\title{
POETIC CHARACTER AND ITS SPECIFIC FEATURES
}

Abstract: The impact of the Eastern literature to the poetry of the Uzbek academician poet Gafur Gulam has been learnt by this article. Through the model of the analyses of poems by the poet poetic character and its specific features have been observed. And also the scientific-theoretical opinions on the specific depiction style and approach, scenic ideas concerning to the Eastern poetry, which have been ahead for formulation the individual style of Gafur Gulam to be talked.

Key words: Poetry, lyric feeling, sense, philosophical pithiness, inheritance, figurativeness, simplicity, coherency, motive, fairy tale, oral epic, blessing, scolding, proverb, parable, sayings, lyric character, outlook, style, cross impact, individuality, authentic ideal, literary-depictive means, idea, content.

Language: English

Citation: Matyakubova TR (2015) POETIC CHARACTER AND ITS SPECIFIC FEATURES. ISJ Theoretical \& Applied Science 07 (27): 40-43.

Soi: http://s-0-i.org/1.1/TAS-07-27-7 Doi: crossef http://dx.doi.org/10.15863/TAS.2015.07.27.7

\section{Introduction}

It's known that the creative works of the ancestors and their literary heritage played an important role for the perfect development of every talented person. Learning creative experience of mentors, continuing their traditions gives the artist the opportunity of affecting the development of literature of his time.

The representatives of the $\mathrm{XX}^{\text {th }}$ century Uzbek literature like Fitrat, Choolpon, Qodiriy, Oybek, Shaykhzoda, H. Olimjon considered Uzbek literature as the organic continuation of the eastern literature. That's why they have learnt the creative artworks of the thinkers of the east, continued their traditions according to their particular creative way. These ideas are also concerned to the famous poet and academic Gafur Gulam. The creative works of ancestors have taken an important role for becoming famous poet, skilful writer, outstanding translator and academic. Gafur Gulam has profoundly translated into Uzbek the samples of many artworks of the representatives of the Farsi- Tajik literature like Abu Abdullo Rudaki, Shaykh Muslihiddin Sadiy, Abdurahmon Jomi, Mirzo Abdulqodir Bedil, Abulqosim Lohutiy, Mirzo Tursunzoda.

The poet from his youth time till the end of his life has perfectly learnt the creative artworks of the famous thinkers of the East, used and developed their traditions creatively.

\section{Cross-impact and mutuality}

The creative heritage of Gafur Gulam has been formulated and developed based on the impact of many authors of the Eastern literature and their valuable creative artworks which have been left by them. The elegance of human feelings, liked by people, deep sincerity in Rudakiy's, heroic spirit, epic scale in Firdavsi's, the great sense in the poems of Hofiz, encircle the universe phenomena as the scale of space in the Nizomi's, deep pithiness, edifying ness in Sadi's, enormity in Jomi's has been immersed into the essence of creative heritage of Gafur Gulam. He followed by the logically clear philosophical thoughts, livid lyrics of Bedil. He expressed his wise thoughts under the impressions of philosophical sayings of Omar Khayyom. He has been influenced on playful tunes of Fuzuli, has got lyric heat from the poet Alisher Navoi.

One of the particular features of creativity of Gafur Gulam are his deep respect to the classical Eastern literature. Gafur Gulam has been true in this feeling and immersed it into the contents of his artworks in different genre during the time of his creative activity. The following words of the scholar on literature A. Haytmetov proofed our thoughts: "Gafur Gulam considered Uzbek literature, particularly, its classical part as the part of the general eastern literature and he appreciated 


\begin{tabular}{|c|c|c|c|c|c|}
\hline Impact Factor: & $\begin{array}{l}\text { ISRA (India) } \\
\text { ISI (Dubai, UAF } \\
\text { GIF (Australia) } \\
\text { JIF }\end{array}$ & $\begin{array}{l}=1.344 \\
=0.829 \\
=0.356 \\
=1.500\end{array}$ & $\begin{array}{l}\text { SIS (USA) = } \\
\text { PUHЦ (Russia) = } \\
\text { ESJI (KZ) = } \\
\text { SJIF (Morocco) }\end{array}$ & $\begin{array}{l}=0.912 \\
=0.179 \\
=1.042 \\
=2.031\end{array}$ & ICV $($ Poland $) \quad=6.630$ \\
\hline
\end{tabular}

learning the history of Uzbek literature in this way'[9].

Gafur Gulam wrote the names of great Eastern poets with respect in his poems, he stated that they were the most skilled and their creative work was a great experimental source for him. Sometimes he capably used specific features of Eastern poets' style for expressing philosophic-aesthetic views in his poems. He used the views about Navoi and Bedil in his poem "Sarhisob" ( "Closing stages") on creating metaphor

Navoi baytiday to'lqinli yoshlik,

Bedilning sh'eriday falsafiy umr,

Vaznu qofiyasi mustahkam hayot

Roman o'qilganday o'tib bormoqda,

Etagi qo'llardan ketib bormoqda [4]

(Meaning of the poetry extract:

Waving youth time as Navoi's verse,

Philosophic life as Bedil's ode,

The lasting life as to line and rhyme

Having passed as a read novel,

Its hem is running away from their hand.)

In this poem Gafur Gulam was able to provide literary clearness by comparing the intensity specific for the youth to Navoi's poems, philosophical thoughts specific for the adults to Bedil's poems. The depiction of forever unchangeable rules of life as the line and rhyme of the poem, and the passing life as reading novel is an unexpected poetic discovery. The couplets like "There will be thousands of "Shohnoma" (Shahname) in our life", "There is some agonize in the ligament as Firdavsi's couplet", "It seemed as if Bedil's gazal in a poem", "It's worth to writing oral epic "Thousands of Shahname" with blood", "'Hamsa" for love and loyalty which was written by Jomiy", "Eternal bay of Navoi", “ It would be good if I wrote the lyrics of peaceful time for my nation as Hofiz's gazals" and other clearly proofed Gafur Gulam's admire, love and aspiration to the Eastern poets

\section{Character and specific features in the poems of the poet}

While talking about the impact of the Eastern literature to the creative work of Gafur Gulam it could be good to note his attitude to the creativity of Omar Khayyam. Gafur Gulam was not only the person who knew his poems by heart, who had strong memory and understood Omar Khayyam's poetry deeply, but he was the person who felt the sense of word art deep in his heart and also well educated person who had eternal love for the Eastern literature deep in his soul. The influence of the treasure of Omar Khayyam to the poetry of Gafur Gulam to be observed through existence of spirit concerned to Khayyam in the literarily interpretation of life and person and also making philosophic- aesthetic conclusions. The most characters created by Gafur Gulam existed the influence of creativity of Omar Khayyam. It is not suprising if the treasure of Omar Khayyam as the other Eastern classical poets played as the role of master class in the creative activity of Gafur Gulam.

There are lots of poems among the creative work of Omar Khayyam depicted the dream of seeing the people in freedom. He wished to see not only the parts of people but seeing all the humanity in freedom and peace. While determining the person's peaceful life with his satiety and peaceful place, at first he appeared as a tolerant person, second as an attentive person who evaluated the time with the level of attitude to an ordinary people:

Kimningki bor esa bir burda noni,

O'ziga yarasha uy-oshiyoni,

Na birov unga qul, na u birovga,

Ayt, shod yashayversin, xushdir zamoni [2]

(Meaning of poetry extract:

If anyone has a peace of bread,

Suitable house and homeland,

Neither anyone slave for nor he is for,

Let him live with joy, in his happy time.)

In the poem,"The sunlight is equal to all nation" to be observed the interpretation of the close views to these ideas.

Har bir ozod kishining

O'z fikri, o'z ishonchi.

Jumla insonlarga xos

Kitobi va tayanchi.

Na birovni qul qilur,

Na birovga bo'lur qul.

Hamma odam yoru do'st,

Qayg'usiz yorug' ko'ngil [6]

(The meaning of the poetry extract:

It's an own hope, it's an own thought,

Of an each free person.

It's a book and support,

Peculiar to all people.

Neither anyone slave,

Nor a slave by himself.

All people are friends,

It's a bright soul freed from sorrow.)

Both of these poems through the interpretation of the notion liberty and freedom there are presented interactive harmony and individuality. For Umar Khayyom the main term of happiness for the members of the society is their free living conditions. As to Umar Khayyom if there is a piece of bread and house for living, it could be enough proof for his free living. With the help of the expression "a piece of bread" in the poem created the synecdoche and it means that there is enough materiality which endow with human's needs. As for lyric hero of Gafur Gulam, all people's friendship and not being a slave guaranteed the happiest and free life of human. There 
is depicted that people could be free and independent if he has his own thoughts and belief. Here the views of Gafur Gulam depicted not only harmoniously with the ideas of Khayyom but the views of the poet are depicted more wider and deeper connecting with enlightenment and belief which served peaceful and free living of people without trouble. The word "book" in the poem, which caused to appear the art synecdoche, expressed that meaning.

\section{Imaginatively interpretation and depiction skill}

The creativity of Gafur Gulam is worth to value of his unrepeated artistic depiction. Academic B. Nazarov wrote about his artworks as following; "The philosophy of life, the philosophy of dear and appreciate its sense covered all the creative life of the poet and it appears with its whole beauty in the depiction of the poetic characters" [1]. The sway of Omar Khayyom on creative work of Gafur Gulam one can notice in his creativeness on depicting specific imaginative expressions. The imaginative thought in his couplet as "Bulbulning ko'ziday nol to'garakka, Bir butun koinot sig'a oladi" ("Insoniyat proframmasi"- "The program of the mankind") (Meaning: The whole world can go in, the zero circle as nightingale's eye), can be noticed the influence on the following couplets of Omar Khayyom: “To'garak jahonni uzuk deb bilsak, Shaksiz uning ko'zi - gavhari ham biz". (Meaning: If we consider the whole world as a ring, undoubtedly, we are its eye - pearl). When Omar Khayyom depicted the world as a ring and the mankind as its eye pearl, through the imaginative power of Gafur Gulam the whole world could go in the zero circle like a nightingale's eye. In actual fact, each creator of East is a mentor and learner to each other.

While Omar Khayyom depicted invaluableness of Wiseman before the ignorance looked like the sky as an overturned basin by the following: “To'nkarilgan jomday ko'rinar osmon, Ostida zabundir kimki bilag'on". (Meaning: The sky can be seen like an overturned basin, under there is depressed wise person.), and Gafur Gulam in his poem "Insoniyat programmasi" ("The program of the mankind") depicted with pride and proudly that before the bigheaded man any eminence is nothing and any ignorance exactly to be failed by expressing as: "Boshi balandligiga ko'kni o'xshatolmayman, Osmon degan nimadir? - To'nkarilgan eski tos" (Meaning: I can't compare his bigheaded to the sky, What is the sky itself? - It's an old overturned basin)

In his poems Omar Khayyom appreciated godly love actively concentrating on the symbolic characters as "may", "boda", "sharob", "kosa", "soqiy" (These words mean "wine", "wine-server"). He depicted true enlightenment and vary inner thoughts of the lyric character. Such kind of traditional characters can be met with in the poems of Gafur Gulom. Poet used these images concentrating on his own time and expressed them in new meaning as appreciating the beauty of life and happy living. Omar Khayyom wrote:

May ichamen, mastlik qilmaymen also,

Qadahdan o'zgacha bo'lmayman balo.

Boda ichishlikdan mening g'arazim -

O'zimga sen kabi qo'ymaslik bino.

(Omar Khayyom. Ruboiylar (Quatrains). P.99)

(Meaning: I drink wine, but I never get drunk,

I'm never dodger different as wineglass

To drink a wine is my self interest -

As I don't want to tend myself like you.)

Above given poem of Khayyom the word "may" ("wine") used as metaphor, "may" ("wine") means - true love, "wineglass" means enlightenment. If we take into consideration that the positive characters of a person enriched when he fell in love, for what purpose the lover drink wine would be clear. So that the meaning of the quatrain could be meant as following: "How much I fell in love, I fill my soul with true enlightenment. The reason of my love is to keep my humanistic character, not to be tended by myself like others".

In the poems of Omar Khayyom "may" ("wine") and the images connected with it has been used many times, and through them the ideas recognition of Trust, self-realization, perceiving the enlightenment to be valued. It seemed us that these images influenced on the creation of the images "soqiy"("wine server"), "may", "sharob” ("wine”), "qadah" ("wineglass") which are met in the poems of Gafur Gulom. Of course, in the poems of Gafur Gulom the meaning connected with these images stressed on outer sense of life. That means there is appeared an imagination concerning to description the features of living and struggling, singing the pleasure of life. But if we carefully observe the poems of Gafur Gulam we can clarify the poems where used the word "may"("wine") and its synonyms, there is also depicted its symbolic meaning.

Gafur Gulom concentrated on the images "soqiy"("wine-server") and "sharob" ("wine") when he depicted the pictures of his time. In this place these images meant as a symbolic essence. The poet in his poem "Qutlug' yil tongi" ("Happy year morning") wrote as following: "Soqiy menga sun qadah, yigirmanchi asrning Ichgan sari kishini hushyor etar sharobin" (V.2. p 224) (Meaqning: "Wine - server give me a wine glass of the twentieth century that makes a man to be attentive while drinking"). On the outer side meaning these couplets can be meant as the feeling appeared while drinking. If we are more attentive, there is found multimeaning inside the content. One can understand the meaning of the words given in the poem as: "wineserver" - the life, "wineglass" - the life given to a person, "wine" is the time. Therefore, the person 


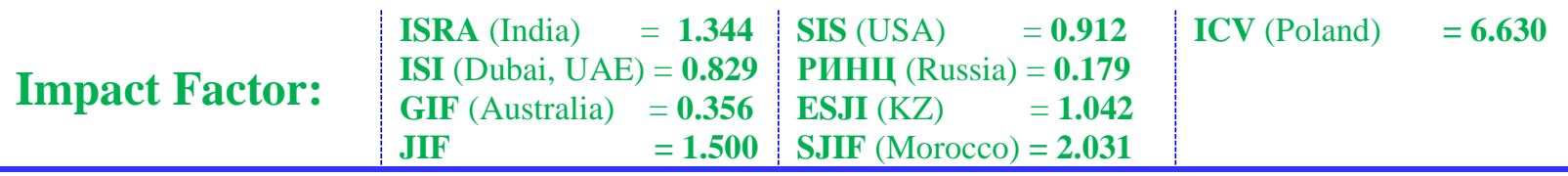

became more careful while living and lessoned learned through their life experience. Especially the man of the $\mathrm{XX}^{\text {th }}$ century, who passed through the events never heard and seen, should be always thoughtful.

In his poems devoted to the depiction of landscape the poet addressed to the image "wineserver". "Barda ko'rpalarni yelkaga qiyg'och tashlab, Uchib qolgan soqiyday gungurs uhlaydi toklar" (V.2. p.152) (Meaning: The Vine trees are sleeping like a drunken man, who stretched out under blanket in the Bar). The natural and unrepeated depiction of the images in this poem is worth to appreciation. The comparison of Vine trees which are sleeping like a drunken man is the discovery of Gafur Gulom.

\section{Conclusion}

It is clear that the influence of Navoi on the creative work of Gafur Gulom is multi edging and it help to enrich and increase the literary creativity of the poet. In many images, depiction styles and means to be observed the influence of traditions of Alisher Navoi. It proofed that he knew the specific features of classical literature very well and used this valuable treasure effectively in his creative work.

Our observations showed that the poet was the outstanding person who gained the knowledge of the secrets of classical treasure very well. The effective usage of the traditions of classic literature in the literary-critical articles, lectures and poems based on clear reviews proofed our thoughts. We hope, it will help to define the sources of creative work of Gafur Gulom and understand his artworks specific features clearly.

\section{References:}

1. Nazarov B (2004) Gafur Gulom olami (The world of Gafur Gulam). - T.: Fan, 2004. pp. 11.

2. Omar Khayyom (1970) Quatrains. - T.: Adabiyot va san'at, (Literature and Art), 1970.

3. Shomuhamedov S (1974) Gumanizm abadiylik yalovi. (Humanism - flag of eternity). - T.: Adabiyot va san'at, (Literature and Art), 1974.

4. Gafur Gulam (1983) Mukammal asarlar to'plami. (Volume of Artworks). 12 Volumed. T.1. - T.: Fan, 1983.

5. Gafur Gulam (1984) Mukammal asarlar to'plami. (Volume of Artworks). 12 Volumed. T.2. - T.: Fan, 1984.
6. Gafur Gulam (1984) Mukammal asarlar to'plami. (Volume of Artworks). 12 Volumed. T.3. - T.: Fan, 1984.

7. Gafur Gulam (1985) Mukammal asarlar to'plami. (Volume of Artworks). 12 Volumed. T.4. - T.: Fan, 1985.

8. (2003) Gafur Gulom and Samarqand. Samarqand, 2003.

9. Haytmetov A (1997) Mumtoz adabiyotimiz bilimdoni. (Scholarly of our Classical literature)// Adabiy merosimiz ufqlari.- T.: O'qituvchi, 1997.

10. Matyoqubova T (2011) Poetic idrok va mahorat. - T., 2011. 